DOI: $10.18276 / \operatorname{sip} .2017 .50 / 1-16$

\title{
Monika Mocianko-Pawlak*
}

Uniwersytet Szczeciński

\section{BEZPIECZEŃSTWO A POZIOM PRZESTĘPCZOŚCI W POLSCE W LATACH 2007-2016}

\begin{abstract}
Streszczenie
Artykuł zawiera charakterystykę pojęcia bezpieczeństwa, przedstawienie typologii bezpieczeństwa, a także zdefiniowanie przestępczości. W opracowaniu wykorzystane zostały dane ze statystyk policyjnych, co pozwoliło na określenie poziomu przestępczości w Polsce w omawianym okresie, oraz dane z badań CBOS w zakresie oceny stopnia poczucia bezpieczeństwa. Celem niniejszego artykułu jest przedstawienie zależności pomiędzy poziomem przestępczości a poczuciem bezpieczeństwa w Polsce w latach 2007-2016.
\end{abstract}

Słowa kluczowe: bezpieczeństwo, przestępczość, statystyka policyjna

\section{Wprowadzenie}

Od początku XXI wieku zauważalna jest nobilitacja bezpieczeństwa w hierarchii potrzeb już nie tylko jednostki, ale przede wszystkim społeczności zorganizowanych: od społeczności lokalnych, przez państwa, do społeczności ponadpaństwowych - globalnych. Bezpieczeństwo staje się ważnym czynnikiem mającym wpływ na rozwój społeczno-gospodarczy państwa oraz jakość życia jego mieszkańców. Zgodnie z art. 5 Konstytucji Rzeczypospolitej Polskiej z 2 kwietnia 1997 r. Rzeczpospolita Polska zobowiązana jest do zapewnienia bezpieczeństwa obywa-

Adres e-mail: mtpawlak@o2.pl 
teli. Aby wywiązać się z powyższego obowiązku, państwo określa swoje cele strategiczne, do których zaliczają się między innymi: zapewnienie korzystnych warunków rozwoju ekonomicznego i społecznego, przeciwdziałanie przestępczości i ochrona obywateli przed bezprawiem. W Strategii Bezpieczeństwa Narodowego Rzeczypospolitej Polskiej z 2014 roku wskazuje się, że ,,potencjał społeczny, w tym kapitał ludzki, jest ważnym czynnikiem warunkującym wzrost gospodarki narodowej, sprawność państwa, aktywność społeczeństwa obywatelskiego oraz ogólną poprawę jakości życia obywateli. Nowoczesny system edukacji publicznej i szkolnictwa wyższego, a także upowszechnienie różnych form uczenia się przez całe życie służą wykształceniu społeczeństwa aktywnego i mobilnego. Istotnym elementem rozwoju kapitału ludzkiego i społecznego jest edukacja na rzecz bezpieczeństwa”.

\section{Bezpieczeństwo - definicje i typologia}

\subsection{Bezpieczeństwo - wybrane definicje}

W zależności od sposobu pojmowania bezpieczeństwa jako potrzeby, stanu, procesu albo wartości znajdujemy różne definicje tego terminu.

Termin „,bezpieczeństwo” wywodzi się z łacińskiego słowa securitas tłumaczonego w pierwszej kolejności jako wolność od trosk, spokój umysłu i w konsekwencji jako pewność, bezpieczeństwo. Etymologia słowa „,bezpieczeństwo” w wielu językach (także w polskim) uwydatnia pierwotność poczucia zagrożenia w stosunku do poczucia pewności swego zabezpieczenia (,,bez pieczy”, czyli bez wystarczającej ochrony i analogicznie z łaciny securitas = sine cura) (Stańczyk, 1996, s. 15). W podstawowym i najbardziej powszechnym znaczeniu bezpieczeństwo oznacza brak zagrożenia. Jak wskazuje Świniarski (1997, s. 56), ,już starożytni filozofowie stworzyli podstawy współczesnego rozumienia bezpieczeństwa, zwracając uwagę, że bezpieczeństwo jest dobrem naturalnym i wspólnym człowieka, które skłania go do starań o nie, do stworzenia warunków gwarantujących trwałość i rozwój życia ludzkiego". Pierwotnie bezpieczeństwo rozumiane było jako potrzeba jednostki. W psychologii potrzebę bezpieczeństwa umiejscawia się pomiędzy potrzebami biologicznymi, czyli pierwotnymi potrzebami człowieka, a potrzebami specyficznie ludzkimi. EiblEibesfeldt (1987, s. 195) reprezentuje pogląd, że z motywacji lękowej wywodzi się ludzka skłonność do utrzymywania porządku, gdzie porządek oznacza orientację w czasie i przestrzeni, i to w odniesieniu nie tylko do wydarzeń przebiegających poza 
ramami gatunku, zaś poczucie bezpieczeństwa uzyskujemy również, gdy możemy przewidzieć, co będą czynić inni.

Bezpieczeństwo jest również określane jako stan niezagrożenia, spokoju, pewności, wolności od zagrożeń, strachu lub ataku. Jak wskazuje Wawrzusiszyn (2011, s. 13), ponieważ „stan” bezpieczeństwa jest niemierzalny, więc zasadniczą kwestią w zapewnieniu bezpieczeństwa jest jego postrzeganie przez społeczeństwo i władze państwa, które w wyniku analizy obiektywnych i subiektywnych aspektów zagrożenia może przybrać - zdaniem szwajcarskiego politologa Freia - następujące postaci:

a) braku bezpieczeństwa - wówczas, gdy występuje duże rzeczywiste zagrożenie, a postrzeganie tego zagrożenia jest prawidłowe;

b) obsesji - gdy nieznaczne zagrożenie jest postrzegane jako duże;

c) fałszywego bezpieczeństwa - gdy zagrożenie jest poważne, a postrzegane bywa jako niewielkie;

d) bezpieczeństwa - gdy zagrożenie zewnętrzne jest nieznaczne, a jego postrzeganie prawidłowe.

W ślad za Stańczykiem (1996, s. 18-19) bezpieczeństwo można definiować nie tylko jako określony stan rzeczy, ale jako ciągły proces społeczny, w ramach którego podmioty działające starają się doskonalić mechanizmy zapewniające im poczucie bezpieczeństwa. $\mathrm{W}$ takim rozumieniu dynamizm kategorii bezpieczeństwa w naturalny sposób wiąże się ze zmiennością warunków otoczenia, postępem cywilizacyjnym i zakresem potrzeb poszczególnych podmiotów.

Kukułka (1982, s. 35) postrzega bezpieczeństwo jako pewien system wartości w połączeniu ze środkami zapewniającymi ich zachowanie, na który składają się:

a) przetrwanie (państwowe, etniczne i biologiczne), któremu każde państwo gotowe jest poświęcić inne wartości, gdyż tracą one sens w przypadku zagrożenia przetrwania samego podmiotu;

b) integralność terytorialna (w sensie fizycznym, narodowym i państwowym);

c) niezależność polityczna (w sensie ustrojowym, samowładności i swobody afiliacji);

d) jakość życia (w sensie poziomu życia, szczebla rozwoju społeczno-gospodarczego i systemu kulturalnego), która wymaga dużo zdrowego rozsądku, aby nie była zbyt maksymalistycznie traktowana.

Według Kukułki zagrożenie którejkolwiek z czterech wymienionych wartości prowadzi do ograniczania żywotnych interesów państw, a tym samym oznacza zmniejszenie bezpieczeństwa narodowego. 
W XXI wieku bezpieczeństwo jest pojmowane całkiem inaczej niż w poprzednim stuleciu. Płynność jego granic i coraz większe problemy z definiowaniem agresora powodują, że bezpieczeństwo nabrało innego wymiaru. Jest ono trudniejsze do przewidzenia i utrzymania, utraciło swój homogeniczny charakter. Nabrało wielofunkcyjnego wymiaru, stając się wartością powszechną, i jest definiowane często jako kategoria zarówno w naukach społecznych, jak i ścisłych (Kochanek, 2011, s. 124).

$\mathrm{Z}$ zamiarem zapewnienia bezpieczeństwa jednostki i grupy społecznej starają się oddziaływać zarówno na swoje otoczenie zewnętrzne, jak i sferę wewnętrzną, aby usuwać, neutralizować lub przynajmniej oddalać zagrożenia, a tym samym eliminować własny lęk, obawy, niepokój i niepewność. Zagrożenia mogą bowiem powstawać wewnątrz samego podmiotu albo napływać z zewnątrz. Dlatego działania w celu ich usunięcia są kierowane zarówno do wnętrza podmiotu (np. struktur państwa), jak i ku sferze zewnętrznej, na przykład środowisku międzynarodowemu. Stąd wywodzi się wyodrębnienie dwóch aspektów bezpieczeństwa: wewnętrznego i zewnętrznego. Bezpieczeństwo wewnętrzne oznacza stabilność i harmonijność funkcjonowania organizmu bądź systemu (np. państwa), natomiast bezpieczeństwo zewnętrzne - brak zagrożenia ze strony innych podmiotów (np. innych państw). Lącznie oba aspekty składają się na ogólne bezpieczeństwo danego podmiotu, na przykład państwa z jego społeczeństwem (Nowakowski, 2009, s. 5).

Koziej (2011, s. 20) wskazuje, że najczęściej bezpieczeństwo definiuje się zarówno jako stan (osiągnięte poczucie bezpieczeństwa danego podmiotu), jak i proces (zapewnianie poczucia bezpieczeństwa podmiotu). Zauważa przy tym, że bardziej praktyczne jest podejście drugie, odzwierciedlające naturalny, dynamiczny charakter zjawiska bezpieczeństwa.

Na podstawie zaprezentowanych definicji bezpieczeństwa zauważyć można, że pojęcie to ewoluowało wraz z rozwojem cywilizacyjnym ludzkości. Brak jest jednej legalnej definicji tego terminu, zaś definicje naukowe niejednokrotnie istotnie się różnią. Przyczyną takiego stanu rzeczy jest niewątpliwie fakt, iż bezpieczeństwo jest przedmiotem badań różnych nauk (m.in. socjologii, psychologii, politologii, prawa, ekonomii), a punktem wyjścia do budowania definicji są różne kryteria charakterystyczne dla danej dziedziny nauki. 


\subsection{Typologia bezpieczeństwa}

Jak wskazano powyżej, zagadnienie bezpieczeństwa odnosi się do niemal wszystkich dziedzin stosunków państwowych i międzynarodowych, a kwestia bezpieczeństwa jest problemem interdyscyplinarnym. Wszechstronny zakres pojęcia „bezpieczeństwo” oraz jego interdyscyplinarne ujmowanie powoduje konieczność jego skategoryzowania jako punkt wyjścia dla dalszych rozważań.

W literaturze przedmiotu można znaleźć wiele typologii bezpieczeństwa. Podłożem dla każdej z nich jest podział bezpieczeństwa ze względu na:

- podmiot ochrony,

- przedmiot ochrony,

- źródło zagrożeń.

Przyjmując za podstawę powyższe kryteria, można wyszczególnić różne rodzaje bezpieczeństwa, co przedstawiono w tabeli 1 .

Tabela 1. Typologia bezpieczeństwa

\begin{tabular}{|c|c|c|c|}
\hline \multicolumn{4}{|c|}{ Bezpieczeństwo } \\
\hline \multicolumn{2}{|c|}{ Podmiot ochrony } & Przedmiot ochrony* & Źródło zagrożeń \\
\hline \multirow{2}{*}{$\frac{\text { W skali mikro }}{\text { W skali makro }}$} & $\begin{array}{l}\text { Bezpieczeństwo } \\
\text { indywidualne } \\
\text { Bezpieczeństwo grupowe } \\
\text { (rodowe, plemienne) }\end{array}$ & $\begin{array}{l}\text { Bezpieczeństwo: } \\
\text { - fizyczne } \\
\text { - militarne } \\
\text { - cywilne }\end{array}$ & $\begin{array}{l}\text { Bezpieczeństwo } \\
\text { wewnętrzne }\end{array}$ \\
\hline & $\begin{array}{l}\text { Bezpieczeństwo państwowe/ } \\
\text { narodowe } \\
\text { Bezpieczeństwo } \\
\text { międzynarodowe } \\
\text { (regionalne, globalne) }\end{array}$ & $\begin{array}{l}\text { - transgraniczne } \\
\text { - ekonomiczne (gospodarcze) } \\
\text { - socjalne } \\
\text { - społeczne } \\
\text { - publiczne } \\
\text { - polityczne } \\
\text { - informacyjne } \\
\quad \text { (tu: cybernetyczne, } \\
\text { antyterrorystyczne) } \\
\text { - ekologiczne } \\
\text { - kulturowe } \\
\text { - religijne } \\
\text { * Katalog nie jest zamknięty. }\end{array}$ & $\begin{array}{l}\text { Bezpieczeństwo } \\
\text { zewnętrzne }\end{array}$ \\
\hline
\end{tabular}

Źródło: opracowanie własne na podstawie Koziej (2011).

Analizując dotychczas zaprezentowane definicje bezpieczeństwa oraz uwzględniając powyższy podział tego pojęcia, za Pokruszyńskim przyjąć można, że bezpieczeństwo w istocie zależy od tego, co dzieje sie wokół nas, od środowiska zewnętrznego i wewnętrznego, z których mogą pochodzić zagrożenia, oraz od nas 
samych, naszego przygotowania merytorycznego w tym zakresie, naszego zdrowia i gotowości sprostania takim zagrożeniom. W tym kontekście Pokruszyński stwierdza, że zasadniczymi składnikami bezpieczeństwa są gwarancje nienaruszalności podmiotu i swoboda jego rozwoju we wszystkich obszarach, co oznacza, że bezpieczeństwo obejmuje zespolenie trzech komponentów podstawowych, czyli zapewnienie trwania, przetrwania i rozwoju podmiotu (państwa), przy czym nie są to równorzędne składniki w tworzeniu systemu bezpieczeństwa. Ponadto wskazuje on, że bezpieczeństwo w syntetycznym ujęciu można bez większego błędu określić jako obiektywną pewność gwarancji nienaruszalnego przetrwania i swobód rozwojowych, zaś współczesne pojęcie bezpieczeństwa w ogólnym systemie pojęć i kryteriów bezpieczeństwa zajmuje pierwszoplanową pozycję w losach jednostek, społeczności lokalnych i narodów oraz państw (Pokruszyński, 2012, s. 64). Zatem stwierdzić można, że zagrożenie przestępczością wyklucza gwarancję nienaruszonego przetrwania i hamuje, o ile nie uniemożliwia, prawidłowy rozwój podmiotu.

\section{Pojęcie i analiza przestępczości w Polsce}

W myśl art. 1 § 1 Kodeksu karnego (t.j. Dz.U. 2016, poz. 1137) przestępstwem jest popełnienie czynu zabronionego pod groźbą kary według ustawy obowiązującej w czasie jego popełnienia. Pojęcie czynu zabronionego zostało natomiast zdefiniowane w art. 115 § 1 k.k. jako zachowanie o znamionach określonych w ustawie karnej. Zaznaczyć przy tym należy, że zgodnie z art. 1 § 2 i 3 k.k. nie stanowi przestępstwa czyn zabroniony, którego społeczna szkodliwość jest znikoma, oraz nie popełnia przestępstwa sprawca czynu zabronionego, jeżeli nie można przypisać mu winy. Cieślak (1995, s. 139) zwraca uwagę, że wykładnia dosłowna pojęcia „czyn zabroniony” dokonana na podstawie powyższego przepisu znaczy tylko to, że czyn jest objęty formalnym zakazem karnym, czyli wypełnia ustawowe znamiona czynu zabronionego.

Z prawnokarnego punktu widzenia przestępstwa dzieli się ze względu na dobra chronione. Według tego kryterium w części szczegółowej Kodeksu karnego klasyfikuje się przestępstwa między innymi przeciwko życiu i zdrowiu, bezpieczeństwu powszechnemu, wolności seksualnej i obyczajności, porządkowi publicznemu, mieniu, obrotowi gospodarczemu.

Natomiast ze względu na stopień społecznej szkodliwości można wyróżnić następujące rodzaje przestępstw (art. 7 i 8 k.k.): 
a) zbrodnię - jako czyn zagrożony karą pozbawienia wolności na czas nie krótszy niż trzy lata albo karą surowszą; zbrodnię można popełnić tylko umyślnie;

b) występek - jako czyn zabroniony zagrożony grzywną powyżej trzydziestu stawek dziennych, karą ograniczenia wolności albo karą pozbawienia wolności przekraczającą miesiąc (stawka dzienna nie może być niższa od 10 zł ani też przekraczać 2000 zł); występek można popełnić nieumyślnie, jeżeli ustawa (Kodeks karny) tak stanowi.

W literaturze przedmiotu można również znaleźć pojęcie ,przestępstwa pospolite", które według Słownika języka polskiego (http://sjp.pwn.pl/) i podanej w nim etymologii słowa „pospolity” oznacza często zdarzający się, wszędzie spotykany, powszechnie występujący; to jest jakich wiele. Pojęcie to jest często utożsamiane z przestępstwami kryminalnymi jako tymi, które zostały popełnione $\mathrm{z}$ chęci zysku. Przestępstwa pospolite generalnie wiążą się - w ocenie społecznej - z większym stopniem naganności. Przestępstwami pospolitymi, które wzbudzają u ludzi stosunkowo największy i trwały lęk, są: kradzieże, kradzieże z włamaniami, napady i rozboje, bójki i pobicia oraz wandalizm.

Źródłami danych o skali przestępczości są głównie statystyki prowadzone przez instytucje stojące na straży bezpieczeństwa. W niniejszym artykule jako podstawę określenia poziomu przestępczości przyjęto statystykę policyjną opartą na danych wygenerowanych z systemu KSIP, sporządzaną na podstawie postępowań przygotowawczych prowadzonych wyłącznie przez Policję (http://www.statystyka.policja. $\mathrm{pl} /$ st/kodeks-karny).

Punktem wyjścia dla dalszego opisu danych jest wskazanie tendencji liczby przestępstw stwierdzonych jako zbioru wszystkich zdarzeń określanych jako przestępstwa na danym terenie w danym okresie, czyli w latach 2007-2016. Wyjaśnić przy tym należy, że pod pojęciem „,przestępstw stwierdzonych” należy rozumieć przestępstwa będące zbrodnią lub występkiem, ścigane z oskarżenia publicznego, w tym także przestępstwa skarbowe, objęte postępowaniem, w wyniku którego potwierdzono zaistnienie czynu zabronionego, natomiast ,przestępstwa wykryte” to przestępstwa stwierdzone, w których ustalono przynajmniej jednego podejrzanego w zakończonym postępowaniu przygotowawczym lub ustalono nieletniego, który według decyzji sądu rodzinnego popełnił czyn karalny do 2013 roku (od 2014 r. Policja nie prezentuje informacji o czynach karalnych nieletnich).

Jak wynika ze statystyk Policji, w 2007 roku stwierdzono 1152993 przestępstwa, z czego wskaźnik wykrywalności wyniósł 64,6\%. Wskaźnik wykrywalności stanowi iloraz liczby przestępstw wykrytych (łącznie z wykrytymi po podjęciu 
z umorzenia) i ogólnej liczby przestępstw stwierdzonych powiększonej o liczbę przestępstw wykrytych po podjęciu postępowań umorzonych w roku ubiegłym lub latach poprzednich - wyrażony w procentach.

Odpowiednio w latach 2008-2016 przedmiotowe dane prezentują się następująco: w 2008 roku - 1082057 przestępstw ze wskaźnikiem wykrywalności 65,9\%, w 2009 roku - 1129577 ze wskaźnikiem wykrywalności 67,1\%, w 2010 roku 1138523 ze wskaźnikiem wykrywalności 67,9\%, w 2011 roku - 1159554 ze wskaźnikiem wykrywalności 68,7\%, w 2012 roku - 1119803 ze wskaźnikiem wykrywalności 67,8\%, w 2013 roku - 1061239 ze wskaźnikiem wykrywalności 67,0\%, w 2014 roku - 867855 ze wskaźnikiem wykrywalności 65,2\%, w 2015 roku - 799 779 ze wskaźnikiem wykrywalności 64,7\%, a w 2016 roku - 748646 ze wskaźnikiem wykrywalności 66,5\%.

Kształtowanie się liczby przestępstw w Polsce w latach 2007-2016 przedstawiono na rysunku 1.

Rysunek 1. Liczba przestępstw stwierdzonych w Polsce w latach 2007-2016

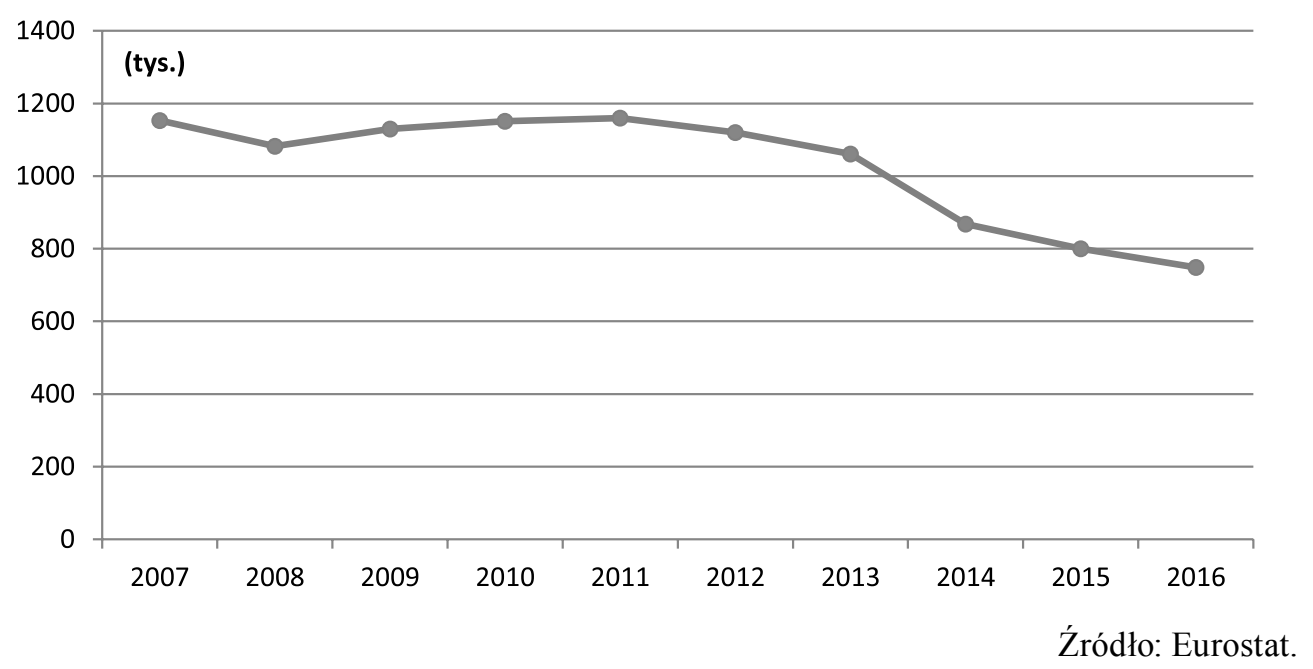

Koncentrując się na najistotniejszych z punktu widzenia poczucia bezpieczeństwa czynach zabronionych, czyli przestępstwach kryminalnych wybranych według siedmiu kategorii przestępstw (tj. bójka i pobicie, uszczerbek na zdrowiu, kradzież cudzej rzeczy, w tym samochodu, kradzież z włamaniem, rozbój - wymuszenia kradzież rozbójnicza, uszkodzenie mienia), poziom przestępczości w Polsce w latach 2013-2016 i wskaźnik ich wykrywalności przedstawia się następująco: 2013 rok - 
727718 przestępstw ze wskaźnikiem 54,9\%, 2014 rok - 589147 ze wskaźnikiem 52,9\%, 2015 rok - 522546 ze wskaźnikiem 51,7\% oraz 2016 rok 490331 ze wskaźnikiem 55\%. Zestawienie zaprezentowanych danych przedstawiono na rysunku 2.

Rysunek 2. Kształtowanie się liczby wybranych czynów zabronionych (stwierdzonych i wykrytych) w Polsce w latach 2013-2016

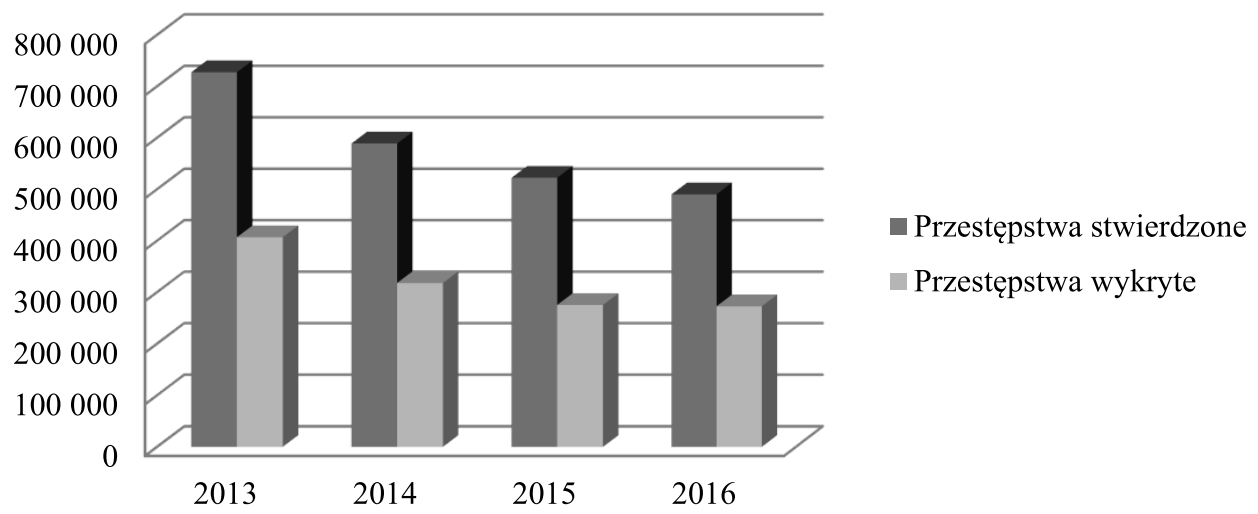

Źródło: opracowanie własne na podstawie danych Komendy Głównej Policji.

Analizując przedstawione dane, obserwujemy spadek liczby popełnianych przestępstw, w tym przestępstw kryminalnych, w latach 2007-2016, co wpisuje się w tendencję spadkową liczby stwierdzanych przestępstw obserwowaną w Polsce już od kilkunastu lat. W 2016 roku odnotowano spadek liczby przestępstw ogółem o 6,39\%, a przestępstw kryminalnych o 6,17\% w stosunku do roku poprzedniego przy jednoczesnym wzroście wskaźnika wykrywalności.

\section{Wpływ przestępczości na deklarowane poczucie bezpieczeństwa}

Opierając się na danych zaprezentowanych przez CBOS (2016, 2017), można wskazać wzajemny stosunek poczucia bezpieczeństwa i poziomu przestępczości.

Badania, których wyniki przedstawiam, zostały przeprowadzone metodą wywiadów bezpośrednich ( face-to-face) wspomaganych komputerowo 12-19 marca 2016 roku na liczącej 1007 osób reprezentatywnej próbie losowej dorosłych mieszkańców Polski oraz 30 marca - 6 kwietnia 2017 roku na liczącej 1075 osób reprezentatywnej próbie losowej dorosłych mieszkańców Polski. Na podstawie uzyskanych wyników 
ustalono, że większość badanych nie obawia się, że może się stać ofiarą przestępstwa $(60 \%)$, a osoby mające takie obawy pozostają w mniejszości (38\%). Blisko połowa badanych (48\%) nie odczuwa obaw ani o siebie, ani o najbliższą rodzinę. Mniej niż co dziesiąty badany ( $8 \%$ ) odczuwa duże zagrożenie przestępczością.

W 2016 roku oceny stanu bezpieczeństwa w Polsce osiągają wysoki poziom. Zdecydowana większość badanych (80\%) uważa Polskę za kraj, w którym żyje się bezpiecznie, natomiast negatywne stanowisko zajmuje tylko $16 \%$ ankietowanych. W 2017 roku poziom poczucia bezpieczeństwa w Polsce wyraźnie wzrasta, osiągając 89\% odpowiedzi twierdzących przy jednoczesnym spadku liczby osób wskazujących na poczucie zagrożenia (9\%).

W celu zbadania prawidłowości statystycznych w zakresie dynamiki (tendencji rozwojowych) oraz związków pomiędzy liczbą przestępstw, poczuciem zagrożenia i sytuacją ekonomiczną w Polsce w latach 2007-2016, analizie poddano następujące zmienne: zbrodnie zarejestrowane przez Policję, deklarowane zagrożenie przestępczością, przemocą lub wandalizmem - badanie UE-SILC, stopę bezrobocia rejestrowanego, PKB per capita, odsetek ludności zagrożonej ubóstwem lub wykluczeniem społecznym.

Tabela 2. Liczba przestępstw, poczucie zagrożenia i podstawowe zmienne ekonomiczne w Polsce w latach 2007-2016

\begin{tabular}{|r|c|c|c|c|c|}
\hline Lata & $\begin{array}{c}\text { Zbrodnie } \\
\text { zarejestrowane } \\
\text { przez Policję } \\
\text { (tys.) }\end{array}$ & $\begin{array}{c}\text { Deklarowane } \\
\text { zagrożenie } \\
\text { przestępczością, } \\
\text { przemocą lub } \\
\text { wandalizmem - } \\
\text { badanie UE-SILC }\end{array}$ & $\begin{array}{c}\text { Stopa bezrobocia } \\
\text { rejestrowanego } \\
(\%)\end{array}$ & $\begin{array}{c}\text { PKB } \\
\text { per capita } \\
(\mathrm{zł})\end{array}$ & $\begin{array}{c}\text { Odsetek ludności } \\
\text { zagrożonej ubóstwem } \\
\text { lub wykluczeniem } \\
\text { społecznym (\%) }\end{array}$ \\
\hline 2007 & 1153 & 8,0 & 11,2 & 30873 & 34,4 \\
\hline 2008 & 1082 & 7,3 & 9,5 & 33446 & 30,5 \\
\hline 2009 & 1130 & 6,7 & 12,1 & 35681 & 27,8 \\
\hline 2010 & 1151 & 6,5 & 12,4 & 37505 & 27,8 \\
\hline 2011 & 1160 & 6,3 & 12,5 & 40649 & 27,2 \\
\hline 2012 & 1120 & 6,3 & 13,4 & 42285 & 26,7 \\
\hline 2013 & 1061 & 6,4 & 13,4 & 43027 & 25,8 \\
\hline 2014 & 868 & 6,4 & 11,4 & 44678 & 24,7 \\
\hline 2015 & 800 & 5,8 & 9,7 & 46812 & 23,4 \\
\hline 2016 & 748 & 5,6 & 8,2 & 48166 & 21,9 \\
\hline
\end{tabular}

Źródło: Eurostat, Bank Danych Lokalnych i Rachunki kwartalne Produktu Krajowego Brutto w latach 2007-2011 i 2012-2016, GUS. 
W zakresie zmian w czasie wyselekcjonowanych zmiennych wykorzystano przyrosty i indeksy statystyczne. Podstawową zmienną informującą o rzeczywistym poziomie bezpieczeństwa jest liczba przestępstw popełnionych $\mathrm{w}$ określonym czasie (np. w skali jednego roku).

W latach 2007-2016 ukształtowała się malejąca tendencja rozwojowa liczby przestępstw w Polsce. Liczba ta spadła o 404,5 tys. przestępstw, z poziomu 1153 tys. zdarzeń zarejestrowanych przez Policję w 2007 roku do poziomu 748 tys. zdarzeń w 2016 roku, co oznacza spadek o 31,1\% w tym czasie, czyli o 4,7\% średnio z roku na rok.

W przypadku poczucia zagrożenia przestępczością, przemocą lub wandalizmem w analizowanym okresie ukształtowała się również tendencja spadkowa, co oznacza, że wraz ze spadkiem liczby przestępstw w Polsce poczucie bezpieczeństwa mieszkańców rosło. Odsetek deklarujących zagrożenie przestępczością, przemocą lub wandalizmem w 2007 roku wyniósł 8,0\% i spadł do poziomu 5,6\% w 2016 roku, czyli o 2,4 p.p.

W tym czasie zmienne ekonomiczne wykazywały różne tendencje rozwojowe, w zależności od ich charakteru. Jeśli chodzi o stopę bezrobocia, to w wyniku kryzysu światowego w latach 2007-2012 ukształtowała się tendencja rosnąca (rys. 4). Dopiero w latach 2013-2016 widać wyraźny spadek stopy bezrobocia w Polsce. Stopa bezrobocia spadła z poziomu 13,4\% w 2013 roku do najniższego poziomu po 1989 roku $-8,2 \%$ w 2016 roku.

W latach 2007-2016 systematycznie poprawiał się dobrobyt mieszkańców w Polsce mierzony wartością PKB w przeliczeniu na jednego mieszkańca. W analizowanym okresie zaobserwowano systematyczny (liniowy) wzrost PKB per capita. W 2007 roku wartość dóbr i usług wytworzonych w gospodarce w przeliczeniu na jednego mieszkańca wyniosła 30 872,8 zł, natomiast w 2016 roku już 48 166,2 zł, co oznacza wzrost o $56 \%$ w całym okresie i 5,1\% średnio z roku na rok.

Wzrostowi dobrobytu mieszkańców towarzyszył spadek odsetka osób zagrożonych ubóstwem. Odsetek osób zagrożonych ubóstwem lub wykluczeniem społecznym w Polsce spadł z poziomu 34,4\% w 2007 roku do 21,9\% w 2016 roku. Średniorocznie odsetek osób zagrożonych ubóstwem lub wykluczeniem społecznym malał systematycznie w latach 2007-2016 o 4,9\%.

Jak widać z przytoczonych tendencji rozwojowych dotyczących bezpieczeństwa i sytuacji ekonomicznej mieszkańców, istnieją silne korelacje pomiędzy tymi dwiema kategoriami zmiennych. Oznacza to, że wraz z poprawą sytuacji ekonomicznej spada nie tylko poziom przestępczości, ale również poprawia się poczucie bezpieczeństwa mieszkańców. Potwierdza to także przeprowadzona analiza korelacji. 
Tabela 3. Macierz współczynników korelacji liniowej Pearsona pomiędzy wyselekcjonowanymi zmiennymi

\begin{tabular}{|l|c|c|c|c|c|}
\hline & {$[1]$} & {$[2]$} & {$[3]$} & {$[4]$} & {$[5]$} \\
\hline$[1]$ & 1 & $\mathbf{0 , 6 3 7}$ & $\mathbf{0 , 6 9 8}$ & $\mathbf{- 0 , 7 8 0}$ & $\mathbf{0 , 7 6 1}$ \\
\hline$[2]$ & $\mathbf{0 , 6 3 7}$ & 1 & 0,145 & $\mathbf{- 0 , 9 2 7}$ & $\mathbf{0 , 9 7 0}$ \\
\hline$[3]$ & $\mathbf{0 , 6 9 8}$ & 0,145 & 1 & $-0,193$ & 0,230 \\
\hline$[4]$ & $\mathbf{- 0 , 7 8 0}$ & $\mathbf{- 0 , 9 2 7}$ & $-0,193$ & 1 & $-0,957$ \\
\hline$[5]$ & $\mathbf{0 , 7 6 1}$ & $\mathbf{0 , 9 7 0}$ & 0,230 & $-0,957$ & 1 \\
\hline
\end{tabular}

[1] Zbrodnie zarejestrowane przez Policję według kategorii przestępstw (tys.).

[2] Deklarowane zagrożenie przestępczością, przemocą lub wandalizmem - badanie UE-SILC.

[3] Stopa bezrobocia rejestrowanego (\%).

[4] PKB per capita (zł).

[5] Odsetek ludności zagrożonej ubóstwem lub wykluczeniem społecznym (\%).

Źródło: obliczenia własne.

Wystąpiła dodatnia, umiarkowana korelacja pomiędzy poziomem przestępczości a poczuciem zagrożenia przestępczością przez mieszkańców $(0,637)$. Silniejsze korelacje wystąpiły pomiędzy poziomem przestępczości a stopą bezrobocia $(0,698)$, PKB per capita $(-0,78)$, odsetkiem osób zagrożonych ubóstwem i wykluczeniem społecznym $(0,761)$. $Z$ badań wynika, że im wyższa stopa bezrobocia, tym wyższa liczba popełnionych przestępstw. Podobnie, im wyższy odsetek osób zagrożonych ubóstwem, tym wyższa liczba popełnionych przestępstw. W przypadku PKB per capita zależność miała charakter ujemny, co oznacza, że wraz ze wzrostem dobrobytu mieszkańców liczba przestępstw malała. Ciekawostką jest, że zaobserwowano silniejsze korelacje pomiędzy poczuciem zagrożenia przestępczością a PKB per capita $(-0,927)$ i poczuciem zagrożenia przestępczością a odsetkiem osób zagrożonych ubóstwem lub wykluczeniem społecznym $(0,970)$. Oznacza to, że poprawa sytuacji ekonomicznej mieszkańców silniej wpływa na poprawę poczucia bezpieczeństwa niż na poprawę samego poziomu bezpieczeństwa. Odpowiednie korelogramy (wykresy rozrzutu punktów) przedstawiono na rysunku 3. 
Rysunek 3. Zależności pomiędzy podstawowymi zmiennymi dotyczącymi bezpieczeństwa i sytuacji ekonomicznej w Polsce w latach 2007-2016

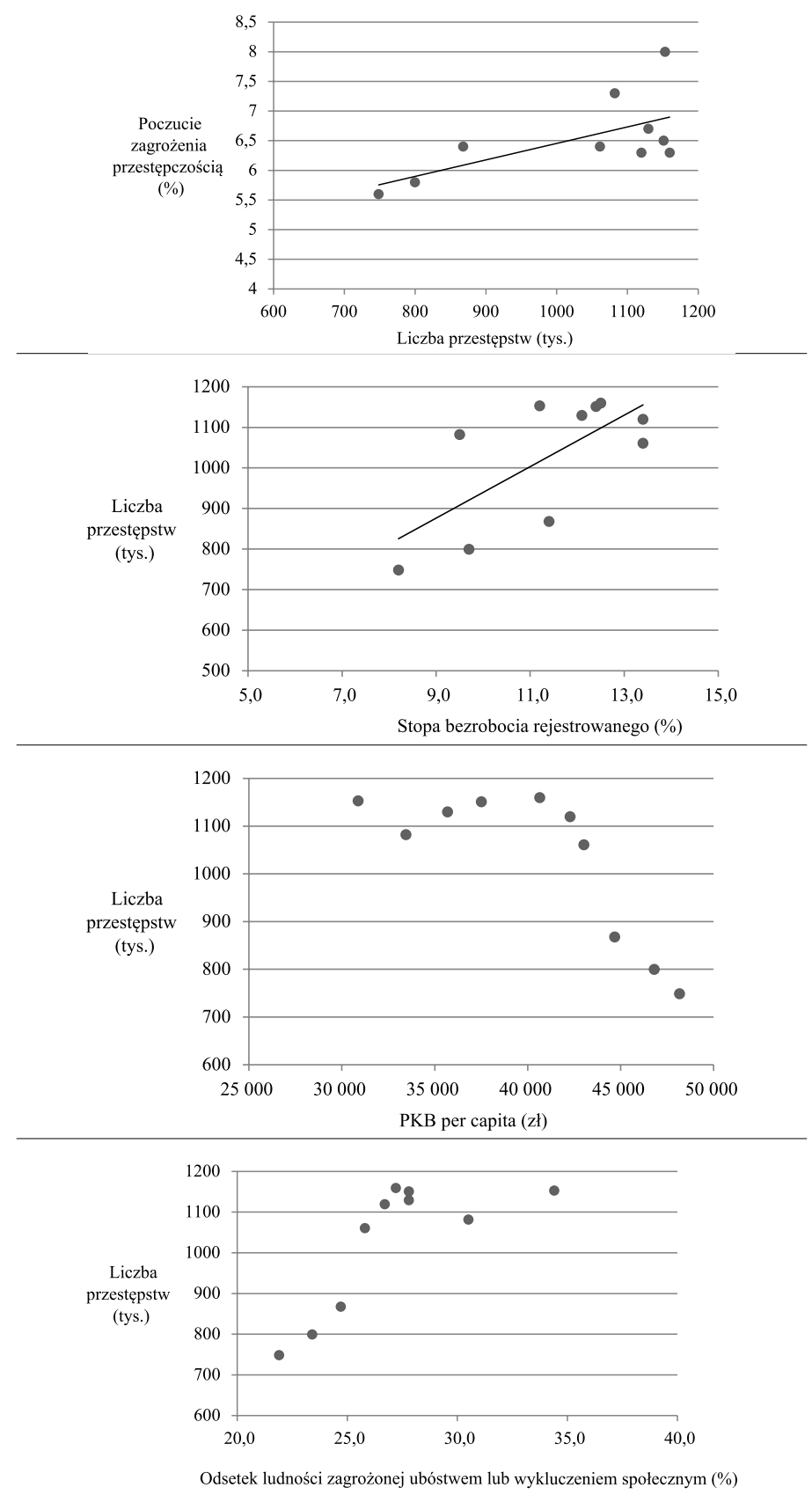

Źródło: opracowanie własne. 
Jak wskazuje Woźniak (2014, s. 136-137), można założyć tezę, że „poczucie bezpieczeństwa jest wypadkową wielu czynników wpływających na ogólną sytuację mieszkańców, bowiem im niższy poziom poczucia bezpieczeństwa, tym bardziej ograniczony obszar aktów działania mieszkańców, ich swobody życia i aktywności, niezależności, ochrony poziomu i jakości życia - to stan poczucia niepewności i zagrożeń wolności i degradacji. Wysoki poziom poczucia bezpieczeństwa społecznego obejmuje zaspokojenie potrzeb: istnienia, przestrzeni, pracy, pewności, stabilności życia mieszkańców".

Na podstawie przedstawionych wyżej danych można również stwierdzić, że poziom świadomości Polaków dotyczący postrzegania bezpieczeństwa jako wartości, a nie wyłącznie indywidualnej potrzeby, także wzrasta. Niewątpliwie na taki dyskurs częściowo wpływ ma też sytuacja międzynarodowa, w tym wszechobecne $\mathrm{w}$ mediach informacje o atakach terrorystycznych w Europie.

\section{Posumowanie}

Na podstawie wyłącznie danych dotyczących poziomu przestępczości w Polsce zaobserwować można pozytywne tendencje, które utrzymują się w latach 20072016, a mianowicie:

- zmniejszenie się ogólnej liczby przestępstw, w tym przestępstw kryminalnych,

- wzrost wykrywalności przestępstw.

Obserwując spadek liczby popełnianych w Polsce przestępstw przy jednoczesnym wzroście wskaźnika ich wykrywalności, można wysnuć tezę, iż poziom bezpieczeństwa jest determinowany przez poziom przestępczości odnotowywany $\mathrm{w}$ danym miejscu, w danym czasie i jest to stosunek odwrotnie proporcjonalny (im niższa liczba przestępstw, tym wyższe poczucie bezpieczeństwa). Jest to niewątpliwie twierdzenie uproszczone, choć usprawiedliwione. W pierwszej części niniejszego artykułu przedstawiono wiele definicji bezpieczeństwa oraz podejść do badania tego zagadnienia. Dlatego też bezsprzecznie podkreślić należy, że bezpieczeństwo zależy od wielu czynników, zarówno w kontekście jego wzrostu, jak i spadku, a nie wyłącznie od poziomu przestępczości, co wykazano w trzeciej części artykułu. Niewątpliwie jednak zapewnienie na odpowiednim poziomie ładu i bezpieczeństwa publicznego należy do podstawowych funkcji państwa zarówno na poziomie centralnym, jak i lokalnym. Realizacja tej funkcji następuje poprzez podejmowanie 
wielokierunkowych działań, zaś przeciwdziałanie przestępczości i podnoszenie jej wykrywalności współcześnie stanowi jedną z podstawowych strategii państwa traktowaną nawet jako jedna z kategorii usług publicznych.

\section{Literatura}

Cieślak, M. (1995). Polskie prawo karne. Zarys systemowego ujęcia. Warszawa: PWN.

Badanie EU - SILC. Europejskiego Badania Warunków Życia. Pobrane z: http://ec.europa. eu/eurostat/data/ database (28.10.2017).

CBOS (2016). Opinie o bezpieczeństwie i zagrożeniu przestępczościq. Pobrane z: http:// www.cbos.pl/SPISKOM.POL/2016/K_061_16.PDF (16.06.2017).

CBOS (2017). Opinie o bezpieczeństwie i zagrożeniu przestępczościq. Pobrane z: http:// www.cbos.pl/SPISKOM.POL/2017/K_048_17.PDF (16.06.2017).

Eibl-Eibesfeldt, I. (1987). Miłość i nienawiść. Warszawa: PWN.

http://www.statystyka.policja.pl/st/kodeks-karny (17.06.2017).

Kochanek, E. (2011). Współczesne interpretacje bezpieczeństwa narodowego. Przeglad Humanistyczny. Pedagogika, Politologia, Filologia, 5, 132-143.

Koziej, S. (2011). Bezpieczeństwo: istota, podstawowe kategorie i historyczna ewolucja. Bezpieczeństwo Narodowe, 18, 19-39.

Kukułka, J. (1982). Bezpieczeństwo a współpraca europejska: współzależności i sprzeczności interesów. Sprawy Międzynarodowe, 7, 29-40.

Nowakowski, Z, Szafran, H., Szafran, R. (2009). Bezpieczeństwo w XXI wieku. Strategie bezpieczeństwa narodowego Polski i wybranych państw. Rzeszów: Wyd. RS Druk Drukarnia.

Pokruszyński, W. (2012). Bezpieczeństwo. Teoria i praktyka. Józefów: Wyd. WSGE im. Alcide De Gasperi.

Przestępstwa ogółem. Pobrane z: http://statystyka.policja.pl/st/przestepstwa-ogolem/121940,Przestepstwa-ogolem.html (17.06.2017).

Raport MSWiA o stanie bezpieczeństwa w Polsce w 2015 r. Pobrane z: https://bip.mswia. gov.pl/bip/raport-o-stanie-bezpie/18405,Raport-o-stanie-bezpieczenstwa.html (16.06.2017).

Słownik języka polskiego PWN. Pobrane z: http://sjp.pwn.pl/ (8.06.2017).

Stańczyk, J. (1996). Wspótczesne pojmowanie bezpieczeństwa. Warszawa: Instytut Studiów Politycznych PAN.

Strategia Bezpieczeństwa Narodowego Rzeczypospolitej Polskiej 2014 r. Pobrane z: https:// www.bbn.gov.pl/ftp/SBN\%20RP.pdf (5.06.2017).

Świniarski, J. (1997). O naturze bezpieczeństwa. Prolegomena do zagadnień ogólnych. Warszawa, Pruszków: ULMAK. 
Wawrzusiszyn, A. (2011). Pojęcie i istota bezpieczeństwa. W: J. Stawnicka, B. Wiśniewski, R. Socha (red.), Zarzadzanie kryzysowe. Teoria, praktyka, konteksty, badania (s. 9-19). Szczytno: Wyd. WSPol.

Woźniak, R.B. (2014). Społeczne wymiary bezpieczeństwa wewnętrznego w mieście portowym. Edukacja Humanistyczna, 1 (30), 133-149.

\title{
SECURITY VERSUS CRIME LEVEL IN POLAND IN 2007-2016
}

\begin{abstract}
The article includes characteristics of the security idea, its typology and an approach to define the crime concept. In order to determine the crime level in Poland through the specific time-lapse the following report presents data from the police statistics along with the sense of security level rated in the specific CBOS research. The purpose of the following report is to evaluate the data dependency between the crime level and the sense of security in Poland in the years of 2007-2016.
\end{abstract}

Translated by Tomasz Pawlak

Keywords: security, crime, police statistics

JEL Codes: F52, H56 